\title{
The post-mortem diagnosis of influenzal infection by fluorescent IgG, IgA and IgM antibody studies on necropsy blood
}

By L. M. DE SILVA, M. S. KHAN, G. KAMPFNER AND J. O'H. TOBIN

Public Health Laboratory, Withington Hospital, Manchester M20 8LR

R. GILLETT

Hope Hospital, Salford

AND C. A. MORRIS

Public Health Laboratory, Royal Salop Infirmary Group Laboratories, Mytton Oak Road, Shrewsbury, SY3 $8 X H$

(Received 10 October 1972)

\section{SUMMARY}

Necropsy blood from cases diagnosed as dying from influenza A was examined for specific antibody in the $\operatorname{IgG}, \operatorname{IgA}$ and $\operatorname{IgM}$ fractions and a specific diagnosis of recent infection was made if either IgM or IgA antibody and low titres of IgG antibody were found. By these criteria a diagnostic rate of $77 \%$ was found in those cases from whom no virus was isolated. The use of infected cell monolayers grown on polytetrafluoroethylene-coated slides gave a simple method of carrying out these antibody assays, and the use of necropsy blood did not require any special methods of transport of specimens to the virus laboratory.

\section{INTRODUCTION}

The virus diagnosis of influenza at necropsy is usually performed on material from the respiratory tract by either the isolation of virus or the identification of virus antigen in it by the fluorescent technique (Hers, van der Kuip \& Masurel, 1968; McQuillin, Gardner \& McGuckin, 1970). Both methods depend for success on the time of death after infection and on the correct collection and handling of specimens. As the humoral antibody response to influenza in the specific $\operatorname{IgG}, \mathbf{A}$ and M fractions usually starts 4-7 days after the onset of symptoms, blood taken at necropsy was examined for specific antibodies to influenza virus in order to see if a diagnosis of recent infection was possible post mortem.

\section{METHODS AND MATERIALS}

Blood taken at necropsy from three groups of patients was studied. The first group consisted of patients from whom influenza A (H3N2) strains were isolated from the respiratory tract; the second of patients with respiratory disease thought to be due to influenza but from whom no virus was isolated; and the third control 
group consisted of those dying from a variety of causes when influenza A was not occurring. Those in the first two groups died during the epidemic of influenza $A$ which ran in Manchester from December 1971 to February 1972, and the controls died during May, June and July 1972 when no influenza A infection was detected. The ages of these patients varied from 55 to 90 in the influenzal groups and from 55 to 85 in the control group. Seven of the 13 patients in group 1, 4 of 13 in group 2, and 17 of the 25 in the control group were males. The patients in groups 1 and 2 died in Salford or Shrewsbury. The control patients in group 3 died in Salford or in Withington Hospital, Manchester.

\section{Virus isolations}

Virus isolations were made from either tracheal swabs or from extracts of lung by inoculation of rhesus monkey kidney cell cultures and the virus was identified by neutralizing haemadsorption with specific antiserum.

\section{Fluorescent antibody studies}

Monolayers of rhesus monkey kidney cells infected with influenza A (H3N2) (A2/Eng/29/70) and VERO monkey kidney cells infected with influenza B (B/Eng/32/71) viruses were used for the detection of fluorescent antibodies by the indirect technique. Darkground microscope slides, which had been thoroughly soaked and washed in haemosol, rinsed three times with demineralized water and twice with distilled water, were stored in methylated spirits until required for PTFE* coating (Goldman, 1968). Twelve or 18 clear disks were left on each slide by screening them with either drops of glycerine or the heads of No. 8 or No. 6 'Posidrive' wood screws during spraying. These PTFE slides were placed in 100 $\mathrm{mm}$. square plastic Petri dishes (Sterilin Limited) and 'sterilized' in a hot-air oven at $60^{\circ} \mathrm{C}$. overnight. Each petri dish contained five slides $(76 \mathrm{~mm} . \times 25 \mathrm{~mm}$.), two of which had been slightly reduced in width by removing a small sliver of glass so that they fitted snugly on the petri dish bottom. Drops of cell suspension containing 300,000 cells per ml. were placed on each of the disks and the cells allowed to grow out for $24 \mathrm{hr}$. at $37^{\circ} \mathrm{C}$. in plastic or glass candle boxes sealed with electrical tape. Plastic boxes were protected from the candle flame by a sheet of aluminium foil. The cell culture growth medium was Parker ' 199 ' with 10\% calf serum, $2 \%$ of $4.4 \%$ sodium bicarbonate solution and the usual antibiotics. After $24 \mathrm{hr}$. the growth medium from each disk was removed with a pasteur pipette and replaced with a drop of maintenance medium (in which $1 \%$ embryo calf serum was substituted for $10 \%$ calf serum) containing from $10^{5}$ to $10^{6}$ influenza virus cell culture infectious doses per $\mathrm{ml}$. The dose of virus chosen showed fluorescent material in approximately $10 \%$ of culture cells after $24 \mathrm{hr}$. incubation. At this time the slides were removed from the Petri dishes and washed twice in buffered saline, twice in acetone and then fixed in acetone for 3-5 min. and air dried for $20 \mathrm{~min}$. The slides were stored at $-30^{\circ} \mathrm{C}$. until required. As slides kept for at least 3 months, batches of 40 to 50 were made at one time. Sera to be tested were inactivated at $56^{\circ} \mathrm{C}$. for

* Polytetrafluoroethylene spray with bonding additive obtainable from Fisons Scientific Apparatus, Loughborough or coated slides $(6 \mathrm{~mm}$. diameter disks) from C. A. Hendley \& Co., Victoria Road, Buckhurst Hill, Essex. 
Table 1. Influenza $A$ (H3N2) fluorescent antibody titres in necropsy sera of patients probably dead of influenza (Dec. 1971-Feb. 1972)

Group 1 (virus isolated)

\begin{tabular}{|c|c|c|c|c|c|c|c|c|c|}
\hline \multirow[b]{2}{*}{$\begin{array}{c}\text { Case } \\
\text { no. }\end{array}$} & \multirow[b]{2}{*}{$\begin{array}{l}\text { Age and } \\
\text { sex }\end{array}$} & \multicolumn{3}{|c|}{$\begin{array}{l}\text { Titre in } \\
\text { serum fractions }\end{array}$} & \multirow[b]{2}{*}{$\begin{array}{c}\text { Case } \\
\text { no. }\end{array}$} & \multirow[b]{2}{*}{$\begin{array}{l}\text { Age and } \\
\text { sex }\end{array}$} & \multicolumn{3}{|c|}{$\begin{array}{l}\text { Titre in } \\
\text { serum fractions }\end{array}$} \\
\hline & & IgG & $\operatorname{IgM}$ & $\operatorname{IgA}$ & & & IgG & $\mathrm{IgM}$ & $\operatorname{IgA}$ \\
\hline 1 & $68 \mathrm{M}$ & 18 & $<6$ & 6 & 14 & $82 \mathrm{M}$ & 6 & 6 & 6 \\
\hline 2 & $77 \mathrm{M}$ & 12 & $<6$ & 6 & 15 & $59 \mathrm{~F}$ & 12 & $<6$ & 6 \\
\hline 3 & $67 \mathrm{~F}$ & $\geqslant 486$ & 54 & 324 & 16 & $74 \mathrm{~F}$ & $\geqslant 486$ & 6 & 486 \\
\hline 4 & $59 \mathrm{M}$ & 18 & $<6$ & $<6$ & $17^{*}$ & $88 \mathrm{~F}$ & 162 & $<6$ & $6^{*}$ \\
\hline 5 & $62 \mathrm{M}$ & $\geqslant 486$ & 12 & 108 & 18 & $80 \mathrm{~F}$ & 18 & $<6$ & 6 \\
\hline 6 & $55 \mathrm{M}$ & 18 & $<6$ & $<6$ & 19 & $79 \mathrm{M}$ & 24 & $<6$ & 6 \\
\hline 7 & $67 \mathrm{~F}$ & 24 & $<6$ & $<6$ & 20 & $72 \mathrm{M}$ & 18 & $<6$ & 6 \\
\hline 8 & $73 \mathrm{~F}$ & 18 & $<6$ & $<6$ & 21 & $87 \mathrm{~F}$ & $\geqslant 486$ & 54 & 54 \\
\hline 9 & $86 \mathrm{M}$ & 80 & $<5$ & 20 & 22 & $90 \mathrm{~F}$ & 18 & 6 & 6 \\
\hline 10 & $64 \mathrm{~F}$ & 640 & 80 & 40 & 23 & $83 \mathrm{~F}$ & 6 & $<6$ & 6 \\
\hline 11 & $54 \mathrm{~F}$ & 45 & $<5$ & $<5$ & 24 & $80 \mathrm{~F}$ & 12 & $<6$ & $<6$ \\
\hline 12 & $55 \mathrm{M}$ & 30 & $<\mathbf{5}$ & $<5$ & 25 & $67 \mathrm{~F}$ & 5 & $<5$ & $<5$ \\
\hline 13 & $75 \mathrm{~F}$ & $\geqslant 405$ & 45 & 45 & 26 & $59 \mathrm{M}$ & 1280 & 160 & 80 \\
\hline
\end{tabular}

half an hour and either screened or titrated using two- or three-fold steps, starting at an initial dilution of either $1 / 5$ or 1/6. Each serum dilution was placed on one disk, this having first of all been demarcated from its neighbour by means of a Shachihata Artline 70 marking pencil. This ensured that one serum sample did not run into its neighbour. The serum dilutions were left on the infected monolayers for one hour at $37^{\circ} \mathrm{C}$. These were washed for 5-10 min. in three changes of buffered saline and stained for $30 \mathrm{~min}$. with specific antigammaglobulin fluorescent conjugates obtained from either Behringwerke (anti-IgG), Nordic (anti-IgM), or Wellcome Reagents Limited (anti-IgG, A \& M). The dilutions of the conjugates used were determined by previous titrations. The preparations were then examined with a Reichert Zetopan microscope fitted with quartz iodine illumination (CradockWatson, Bourne \& Vandervelde, 1972).

\section{RESULTS}

The individual antibody titres of influenza A virus (H3N2) in the IgG, IgM and IgA globulin fractions for the two groups of respiratory disease patients are given in Table 1. The numbers with different titres to IgG, IgM and IgA in the control group are given in Table 2 and a summary of the findings with the number of serological diagnoses of recent influenza from these single specimens of necropsy blood is given in Table 3 .

Seven sera from the 13 patients in whom influenza $A$ virus (H3N2) was found had either IgA and/or IgM antibody present, or IgA and titres of IgG of less than $1 / 100$, the latter indicating that the IgG titres were rising and had not yet reached those associated with convalescence. In those cases not yielding virus, 10 of the 
Table 2. Influenza A (H3N2) virus fluorescent antibody titres in 25 control necropsy sera (May to July 1972)

\begin{tabular}{cccc}
$\begin{array}{c}\text { Antibody } \\
\text { titre }\end{array}$ & \multicolumn{3}{c}{ No. with given titre of } \\
$<5$ & $\operatorname{IgG}$ & $\operatorname{IgM}$ & $\operatorname{IgA}$ \\
5 & 3 & 25 & 24 \\
15 & 0 & 0 & 1 \\
45 & 8 & 0 & 0 \\
135 & 11 & 0 & 0 \\
& 3 & 0 & 0
\end{tabular}

Table 3. Fluorescent antibodies to influenza A (H3N2) virus in necropsy sera

$\begin{array}{ccccccc} & & & \text { Serologi- } \\ \text { cally indi- }\end{array}$

Possible

clinical

influenza

Yes

13

13

13

13

4

5

3

0

54

Feb. 1972

Controls

Not

June-July tested

25

22

0

0

1

0

1972

* Recently vaccinated.

13 sera had these findings in contrast to the control group in whose sera IgM antibody was absent and only one had IgA antibody present. The presence of IgA in this case was associated with an IgG level of more than 1/100. In group 2, in which no virus was isolated, one patient who had been immunized had IgA but no IgM, and an IgG antibody titre of $1 / 162$. As these titres could have been a sequence of vaccination and not natural influenzal infection no retrospective diagnosis could be made.

Five of the seven patients with high levels of IgG, IgM and IgA antibodies had given a definite history of influenza or respiratory disease for a week or more, while the remaining two were stated to have had acute lower respiratory symptoms for only $24 \mathrm{hr}$. before death. All those with low antibody titres had a history of respiratory disease of less than a week, except one woman with leukaemia - a disease which might have affected her antibody response.

Serum end-points were taken as the highest dilution which gave obvious fluorescence. Dilutions giving fluorescence which was probably specific but of poor intensity were ignored. This latter degree of fluorescence was not seen in any of the control sera, but was present in two of the sera from patients yielding virus and in two of those who were virus-negative. 
All but two of the sera from the respiratory deaths had antibodies to influenza $B$ in the IgG fraction, but none had any in the IgA or IgM fractions. In the control group one man had $\operatorname{IgA}$ and $\operatorname{IgM}$ antibodies to influenza $\mathrm{B}$, indicating recent infection. This man lived in an area where one of the only two influenza B viruses isolated this summer in Manchester was found. He had a long history of heart disease but suffered from a 2 -week period of general malaise finishing 2 weeks before his death. This was due to multiple thrombi associated with heart disease, and the myocardium contained numerous areas of healing degenerative foci highly suggestive of a recent myocarditis.

\section{DISCUSSION}

The use of necropsy blood for the post-mortem diagnosis of influenzal infection appears to be a helpful adjunct to virus isolation, which in our hands was only successful in half our suspected cases. Using the presence of $\operatorname{IgM}$ or $\operatorname{IgA}$ with low levels of IgG as the criteria of recent influenzal infection, $77 \%$ of cases suspected of influenza, but from whom no virus was isolated, could be diagnosed. Even if the history of illness was apparently only $24 \mathrm{hr}$. a diagnosis was sometimes possible. By combined virus isolation and antibody determination, diagnosis was achieved in $88 \%$ of our respiratory cases, presuming that all 26 were in fact due to influenza.

Necropsy blood is easily obtained and can be sent to the virus laboratory without any of the special precautions necessary for materials used for virus isolation. Immediate necropsy is not necessary as the efficiency of the fluorescent antibody technique is not affected by possible delay in receiving the blood at the laboratory. The method of antibody assay used is simple, as up to 18 serum dilutions can be tested on a single slide, and these can be prepared in batches and kept frozen until required.

Cell cultures on PTFE-coated slides have also been satisfactorily used for the estimation of antibodies in the specific immunoglobulin fractions with mumps, measles, herpes simplex virus, cytomegalovirus, adenoviruses and some enteroviruses. With monkey kidney cell suspensions the monolayers will readily grow out on the disks in individual drops, but with continuous cell lines or with fibroblast cells it is preferable to flood the slides with growth medium after the cells have settled on the glass, otherwise some of the cell monolayers may not spread out, the size of the individual drops being very critical with these cells. In practice those viruses which need more than $24 \mathrm{hr}$. to produce a fluorescent effect are mixed with the cell suspension at the time of seeding the slides, and subsequent inoculation of prepared monolayers with virus is not necessary.

Our thanks are due to Dr M. Symons of the Royal Salop Infirmary, for samples of necropsy blood; to Dr E. Tapp and Dr J. S. Whittaker for allowing one of us to take blood from their cases at Withington Hospital; to Dr C. M. Patricia Bradstreet for a supply of myxovirus antisera for the identification of influenza virus; to Dr Marguerite S. Pereira for numbering the strains of influenza used in the antibody tests; and to Dr F. T. Perkins for supplying monkey kidney cells. 


\section{REFERENCES}

Cradock-Watson, J. E., Bourne, M. S. \& Vandervelde, Elise M. (1972). IgG, IgA and IgM responses in acute rubella determined by the immunofluorescent technique. Journal of Hygiene 70, 473.

Goldman, M. (1968). Fluorescent Antibody Methods, p. 148. New York \& London: Academic Press.

Hers, J. F. Ph., van Der KuIP, L. \& Masdrel, N. (1968). Rapid diagnosis of influenza. Lancet i, 510.

MoQuillin, Joyce, Gardner, P. S. \& McGuckin, Rosemary. (1970). Rapid diagnosis of influenza by immunofluorescent techniques. Lancet ii, 690 . 